\title{
23. Family sociological theories questioned: Same-sex parent families sharing work and care
}

\author{
Marie Evertsson, Madeleine Eriksson Kirsch, and \\ Allison Geerts
}

\section{INTRODUCTION}

The rapid progress in the legal recognition of same-sex couples that has occurred in recent decades has contributed to an increase in the number of children brought up in these families. Together with the legitimisation of same-sex unions in many European countries, several pathways to parenthood for these couples have emerged, including co-adoption, second-parent adoption, donor insemination, in-vitro fertilisation (IVF), and surrogacy. While these legal developments indicate that levels of acceptance of LGBTQI ${ }^{1}$ families have been rising, this progress has not been universal. As of May 2019, same-sex parenthood was not yet legally recognised - i.e., same-sex couples were not permitted to adopt or to access medically assisted insemination (MAI) - in a number of European countries, including the Czech Republic, Italy, Lithuania, and Poland (ILGA-Europe 2019). Moreover, in February 2019, the Dutch National Healthcare Institute demonstrated that earned rights are also reversible by announcing that health insurance providers are no longer required to cover the cost of artificial insemination for female same-sex couples, and that only couples with a medical condition associated with infertility will be covered (National Healthcare Institute 2019a). In response to pressure from activists and interest groups, this measure was put on hold pending the outcome of further deliberations in 2020 (National Healthcare Institute 2019b). In this chapter, we focus on the Netherlands and the bigger Nordic countries of Sweden, Norway, Denmark, and Finland. These countries were international leaders in the legalisation of same-sex union formation, marriage, and parenthood. However, as much of the literature on same-sex couples stems from the United States (US), we discuss studies conducted in the US (and in other countries) that report patterns, experiences, and narratives that may be applicable to couples across contexts.

The aim of this chapter is to critically evaluate and discuss family sociological theories and perspectives from the point of view of same-sex couples and families. We also discuss the legal developments for same-sex marriage and parenthood in the countries in our study sample. In particular, we discuss how, when, and why the experiences of same-sex parent families challenge traditional family sociological theories. Focusing on the division of paid and unpaid work, and care, our two main questions are as follows: First, to what extent do - often supposedly gender-neutral - theories hold when the family being studied is not a heterosexual, nuclear family? Second, where does the inclusion of same-sex families leave us when it comes to formulating a family sociology for the future?

Before we start, it is important to clarify our terminology. When we refer to same-sex, lesbian, and gay couples or parents, we base the categorisation on individuals' (or their partners') reports of their sex in surveys or interviews, or the sex reported in population registers. This definition does not necessarily correspond with individuals' sexual identity or experience 
of gender, and this is a limitation that is worth keeping in mind. It should also be noted that when it comes to the concept of family, the LGBTQI community has historically had a more inclusive definition of what constitutes a family than the general public (Hull and Ortyl 2019; Weston 1991). In this chapter, we define family more narrowly as consisting of parents and children. Although our definition may not always correspond to that of the individuals we focus on, it enables us to use the experiences of same-sex parent families as a lens through which we can analyse the traditional family sociological field. This field is rooted in a heteronormative $^{2}$ concept of a family as consisting of a mother, a father, and one or more children.

\section{CONTEXT, THEORIES, AND PRIOR RESEARCH}

In Europe, the number of countries that have legalised same-sex unions and parenthood increased from zero in 1985 to 24 in 2019 (Waaldijk 2018). The Nordic countries were among the first to acknowledge same-sex relationships through legislation on registered partnerships. Denmark took the lead in 1989, followed by Norway (1993) and Sweden (1995). The Netherlands joined this list in 1998, and Finland joined it in 2002 (Frantzen 2011; Waaldijk 2017). Second-parent ${ }^{3}$ and joint adoption by same-sex couples has been permitted since 1999/2010 in Denmark, since 2002/2009 in Norway, since 2009/2017 in Finland, and since 2003 in Sweden. In the Netherlands, same-sex couples have been allowed to adopt domestically since 2001, and internationally since 2009. Lesbian couples have been permitted to use MAI and IVF services in clinics (private and public) since 2002 in the Netherlands, since 2005 in Sweden, since 2006 in Denmark, since 2007 in Finland, and since 2009 in Norway (Evertsson et al. 2020).

Having access to MAI/IVF has made it much easier for lesbian couples to become parents. Male same-sex couples have transitioned to parenthood in smaller numbers, partly due to the difficulties these couples face in asserting formal adoption rights. Surrogacy (i.e., when a woman agrees to become pregnant and give birth to a child on behalf of another person or couple who will be the child's parent(s)) is illegal in Finland and Norway, and is not legally recognised or regulated in Sweden and Denmark (Evertsson et al. 2020). The Netherlands allows altruistic, but not commercial surrogacy. This means that it is illegal to advertise for a surrogate, or to pay a surrogate more than an amount that covers her health-care expenses and other costs related to pregnancy and birth.

Historically, research on same-sex couples was dominated by qualitative studies. This is partly because many of the research questions posed are concerned with the experiences and narratives of individuals, which are best investigated through in-depth interviews. Moreover, the options for quantitative research were limited, as same-sex couples were difficult to identify in quantitative data sources. But as legal recognition of same-sex couples has expanded, the attention paid to these couples in quantitative studies has also increased. Even so, because the numbers of such couples are small, attaining a sample large enough to make statistical claims about how same-sex couples divide work and care has been challenging. Research in this field has relied on data from population registers (e.g., Aldén et al. 2015; Evertsson and Boye 2018; Kolk and Andersson 2018), large-scale surveys or censuses (e.g., Jaspers and Verbakel 2013; Jepsen and Jepsen 2015), surveys that oversampled the LGBTQI population (e.g., Fischer et al. 2016; Perlesz et al. 2010), or combined multiple surveys (e.g., van der Vleuten et al. 2021). A recurring problem has been that it is difficult to reliably identify same-sex couples in data 
not meant to (over)sample this group (e.g., Gates 2010). In a review of data from countries that legally recognise same-sex unions, Cortina and Festy (2014) pointed to problems with the various measurements used, and recommended caution when making international comparisons of same-sex couples and families.

Because parenthood is rarer for male than for female couples, there is less research on gay fathers than on lesbian mothers (Doucet and Lee 2014; Moore and Stambolis-Ruhstorfer 2013). Among the common themes that emerged in earlier research are identity formation (e.g., Hequembourg and Farrell 1999), the desire to procreate (e.g., Bos et al. 2003), paths to parenthood (e.g., Chabot and Ames 2004; Malmquist and Nelson 2014), well-being and school outcomes among children (e.g., Aldén et al. 2017; Boertien and Bernardi 2019; Mazrekaj et al. 2019), parental stress (e.g., Bos 2010), encounters with health-care providers (e.g., Malmquist 2015), and experiences navigating the legal system (e.g., Compton and Baumle 2015; Park et al. 2016). In this chapter, we focus on the division of work and care in same-sex parent families and couples, and examine the extent to which the research findings map onto or challenge traditional family sociological theories and perspectives.

\section{THE DIVISION OF WORK AND CARE: THEORETICAL PERSPECTIVES AND EMPIRICAL EVIDENCE}

\subsection{The Division of Paid and Unpaid Work}

According to specialisation theory, the gendered division of work in heterosexual couples can be explained by the desire of the partners to maximise household utility (see also Grunow in this volume). In order to maximise utility, the partner with the comparative advantage in labour market work (i.e., the one with the highest expected returns or wages) should specialise in paid work, whereas the partner who is most proficient in care and housework should specialise in those tasks. By specialising, each partner gets better at what they do (e.g., either earning money or producing cost-efficient and healthy meals, providing care, etc.). Following Becker's (1991) reasoning, we would expect to observe fewer benefits from specialisation among same-sex couples because the partners lack physiological sex differences (in particular, that only one partner is able to give birth and breastfeed), and have similar experiences of socialisation and of potential sex discrimination in the labour market. Indeed, studies that compared same-sex couples to different-sex couples have found that same-sex couples distribute housework more equally than their heterosexual counterparts (see Goldberg 2013 for a review). It has also been reported that compared with different-sex couples, specialisation is less common in male (e.g., Goldberg 2010; Kurdek 1993, 2007; Perlesz et al. 2010) and in female same-sex couples (e.g., Aldén et al. 2015; Antecol and Steinberger 2013; Evertsson and Boye 2018; Perlesz et al. 2010). This pattern has been found in several countries (Bauer 2016; Evertsson and Boye 2018; Jaspers and Verbakel 2013; Moberg 2016; Perlesz et al. 2010; Van der Vleuten et al. 2021). Overall, these findings are in line with expectations from specialisation theory (Becker 1985, 1991).

Even small differences in relative advantages in performing paid work and care tasks may have long-term effects on family utility once couples specialise. Full specialisation is seldom financially beneficial for any working-age couple in societies in which childcare is subsidised or inexpensive, and/or the gender wage gap is small. Still, partial specialisation may be 
beneficial, especially during the early childrearing years. According to Becker (1991), the benefits of specialisation increase with the length of the relationship and with the degree of formalisation. Using survey data from seven countries, Bauer (2016) found that specialisation increased in lesbian couples over time (see Grunow et al. 2012 for heterosexual couples in Germany). However, Aldén et al. (2015) reported that specialisation did not increase among lesbian couples in Sweden after they formalised their union by registering the partnership. Their findings also indicated that for gay couples, entering a registered partnership increased the probability of income pooling. In the Netherlands, Jaspers and Verbakel (2013) found that cohabiting same-sex and different-sex couples were not only significantly different from each other in terms of their division of paid work, but also that different-sex couples specialised more than same-sex couples did after marriage.

Becker's theory leaves no room for power differences or differences in preferences between the partners (England and Budig 1998). A theory that considers such factors is the relative resource or bargaining perspective (Blood and Wolfe 1960; Lundberg and Pollak 1996). When their preferences differ, the partners need to negotiate the outcome. In such negotiations, the partner with more resources has more power and will be better positioned to negotiate her or his preferred deal. Examples of power resources are income, love and levels of relationship commitment, and the social transfers, often linked to parenthood, the partners are entitled to receive if they decide to leave the relationship (e.g., England and Farkas 1986; Lundberg and Pollak 1996). While research has shown that, on average, same-sex couples share housework more equally than different-sex couples do, when disparities are reported, differences in time and resources often shape the distribution between the partners. ${ }^{4}$ These findings suggest that same-sex couples, as well as different-sex couples, are influenced by status and power differences (Goldberg 2013, p. 88).

The question of how gender should be conceptualised and understood in same-sex couples has been of major interest in the field. According to West and Zimmerman (1987), gender is not a static characteristic, but is instead constructed through everyday actions and interactions with others. When individuals 'do gender', they conduct themselves in a manner that is in line with the activities expected of their sex category. The doing of gender becomes a self-regulating process in which individuals monitor their own and others' behaviour. If 'doing gender' is unavoidable and is present in everyday interactions, it should also be a driving force in how lesbian and gay individuals spend their time. Like West and Zimmerman (1987), Butler (1990) conceptualises gender as performative. However, Butler (1990) puts the construction of gender outside of the self, thereby integrating discourses of power as well as sexuality. Important contributions have also come from Black feminists (Collins 1990; Crenshaw 1989), who have identified gender as 'an axis of oppression intersecting with other axes', such as sexuality and race (Risman and Davis 2013, p. 742). According to Risman and Davis (2013), theorising gender as a system that intersects multiple axes of inequalities has become 'the new consensus' among social scientists.

Some researchers have characterised same-sex couples, and particularly lesbian couples, as being essentially 'gender-free'. This assumption builds on the argument that the absence of the male-female juxtaposition makes it impossible to assign household and work according to traditional gender roles (Dunne 1998; Evertsson and Boye 2018; Perlesz et al. 2010). However, even if gender polarisation is absent, gendered practices may not be. For example, Carrington (1999) found that lesbian women tended to over-report, while gay men tended to under-report, the time they spent on domestic work. According to Barrett (2015), lesbians who perform little 
housework and gay men who perform a lot of housework may be subject to stigma for challenging gender norms. In the Netherlands, Jaspers and Verbakel (2013) found that it was more common for male same-sex partners to both work full time, whereas it was more common for female same-sex partners to both work part time. In other words, many of the couples acted in line with gender norms and expectations for men and women.

In a critique of LGBTQI family studies for not paying attention to butch and femme ${ }^{5}$ gender identities, Lev (2008) stressed the importance of acknowledging that the lesbian identity is multifaceted and complex. Butch-femme couples might be rendered invisible by the dominant sameness narrative often ascribed to lesbian households. Lev argued that from the outside, a butch-femme couple might appear to be heteronormative, or to be imitating a heterosexual couple, even though their relationship is not gender-hierarchal or traditional 'from the inside' (2008, p. 137). Also among heterosexual couples, identities, gender ideals, and norms can diverge, which challenges the notion that 'woman' and 'man' are universal, homogenous categories (Hines 2015). Yet it appears likely that (hetero)normative family ideals and scripts influence different-sex couples more than same-sex couples (Goldberg 2013; Tornello et al. 2015).

\subsection{Transition to Parenthood and the Division of Work and Care}

When couples become parents, within-couple specialisation often arises in response to the dual pressures of caring for a young child while financially maintaining the household. Research on different-sex couples has also identified the transition to parenthood as the most important factor contributing to gender inequalities in the labour market and in the home (Angelov et al. 2016; Cooke 2014). In one of the first qualitative studies of the transition to parenthood among lesbian couples, Goldberg and Perry-Jenkins (2007) found few indications of specialisation; reporting that in the 29 couples they interviewed, the equitable division of domestic work was maintained. Based on a study of the division of work among 66 lesbian and heterosexual parents, Patterson et al. (2004) found that egalitarian ideals were more important for the division of work in lesbian couples than in heterosexual couples. They observed that in the latter group, structural factors such as work hours and number of children had more weight in predicting the division of childcare and housework. Using register data, Evertsson and Boye (2018) investigated the division of parental leave in female same-sex and different-sex couples in Sweden. During the study period, the parents could share 480 days of leave between them. Their results showed that the amount of leave taken by the birth mother (i.e., the mother who gave birth to the child) was considerably greater than the amount taken by her partner in both same- and different-sex couples (see also Moberg 2016). Although same-sex parents are not expected to 'do gender' by doing difference (i.e., to 'do' motherhood and fatherhood) (West and Fenstermaker 2002), norms on breastfeeding and the child's need for its birth mother are strong. Consequently, birth mothers typically take the first and the longest leave period. However, social mothers usually take a much larger share of the leave than heterosexual fathers do, which indicates that gender norms play a role in within-couple divisions of work and care in different-sex couples (Evertsson and Boye 2018; see also Rudlende and Lima 2018 for Norway). In line with this observed pattern, and partly as a consequence of it, studies that compared income development in same-sex and different-sex couples in Sweden and Norway have shown that five years after childbirth, the income gap was non-existent in female 
same-sex couples, whereas in different-sex couples, the father typically had a notably higher income than the mother (Eckhoff Andresen and Nix 2019; Moberg 2016).

Rosenbaum (2019) studied female same- and different-sex couples who adopted a child in Denmark, and found that female same-sex couples tended to share the leave more equally than different-sex couples did. In addition, Moberg (2017) found that the share of the leave taken by each of the parents in different-sex couples was similar regardless of whether the children were biological or adoptive. Among the advantages of focusing on adoptive parents are that in these couples, the impact of physiological differences linked to sex is eliminated, as neither of the (same-sex or different-sex) parents are breastfeeding or suffering from birth-related health problems; and they all face a similar prolonged process of becoming parents. Rosenbaum's (2019) results indicated that heterosexual mothers experienced greater financial penalties than lesbian mothers did after having a child. This was mainly because heterosexual mothers were more prone to reduce their working hours after childbirth. Rosenbaum (2019) found little evidence that within-couple bargaining or relative resources influenced the child penalty. Even lesbians with low bargaining power (and low relative resources) were shown to experience smaller penalties after having a child than heterosexual mothers. In other words, the evidence indicates that gender was of greater importance than relative resources.

A notable difference between lesbian and heterosexual parents is that a lesbian couple can choose to 'switch' the partner who bears the child if they want more than one biological child. Following Becker's reasoning $(1985,1991)$, the rational choice would be to have the same partner serve as the birth mother, given that the partner who gave birth to the first child has already invested heavily in home production. It appears, however, that Becker's prediction does not hold for many lesbian couples. Perhaps not surprisingly, research has shown that the choice of the birth mother has a significant impact on the income gap for same-sex couples. There is, for example, evidence that couples who switch the birth mother from the first to the second child have more similar income trajectories than couples who do not (Moberg 2016).

The division of labour among gay fathers has not received as much attention as that among lesbian mothers (Oerton 1997; Tornello et al. 2015). Tornello et al. (2015) were among the first to investigate how gay fathers distribute paid and unpaid work, including childcare responsibilities. In a study of 52 gay couples who became parents through surrogacy, they found no correlation between income and participation in housework, and thus dismissed the relative resource perspective. Time constraint theory, however, predicted both the division of childcare and housework among these fathers, as, on average, the spouse who spent fewer hours in paid employment performed more of the unpaid work in the home. Still, it is worth noting that decisions regarding time use are often linked to income. It is, therefore, possible that relative resources (or initial income) and couple bargaining determined which (if any) of the partners reduced the time spent in paid work.

\subsection{Negotiating Parenthood in a Heteronormative Context}

When lesbian women and gay men become parents, they not only challenge hegemonic notions of masculinity and femininity (Stacey 2006) or of gay and lesbian identities, but the meaning of parenthood and family, as they are situated 'at the heart of broader discussions of family politics' (Moore and Stambolis-Ruhstorfer 2013, p. 493). Fatherhood and motherhood have different cultural meanings, and the question of how these meanings influence and inform the social lives of gay and lesbian parents has long been of interest to scholars. Hequembourg and 
Farrell (1999) argued that lesbian motherhood is a complex identity, intersecting a marginalised position (sexual minority) with one of the most revered female mainstream identities: namely, motherhood. Interviews with lesbian birthmothers, stepmothers, and social mothers have shown that lesbian mothers tend to develop strategies for maintaining their motherhood identity as well as their lesbian identity; and an awareness of where, when, and for whom each of these identities is needed. In line with Hequembourg and Farrell (1999), Moreira's (2018) study of lesbian/queer mothers in Spain showed that the interviewees needed to 'justify themselves as being "good" mothers or in "normal families"" (Moreira 2018, p. 15). This observation is also in line with reports from interviews with divorced lesbian mothers, which indicated that these women were struggling to deal with messages of blame for violating the heteronormative model of married/cohabiting parenthood by divorcing (Allen and Goldberg 2019).

Meanwhile, fathers in same-sex relationships often report having to navigate a world that considers several key aspects of their identity irreconcilable (Carroll 2018a). The literature has documented how gay fathers who are exposed to discrimination in the process of becoming parents experience and react to unwanted social interactions with outsiders (Vinjamuri 2015), and how they overcome their own internalised notions that gay men cannot or should not be fathers (Brown et al. 2009; Silverstein et al. 2002). In a small-scale quantitative study for the Netherlands, Bos (2010) showed that although gay fathers did not differ from fathers in different-sex relationships when it came to emotional involvement or parental concern, the former scored higher on parental stress and reported feeling less competent in their childrearing role than the latter. These higher levels of parental stress were related to feelings of rejection, and to the sense that they needed to defend their identity as a gay father. Such findings indicate that minority stress, or heterosexist strain (Silverstein et al. 2002), can spill over into family life. In a qualitative study conducted in the US, Carroll (2018b) highlighted the diversity within the community of gay fathers. She showed that certain groups, such as fathers of colour, single fathers, and fathers who have children from previous heterosexual relationships, were more marginalised in the community, and that these groups developed strategies and resilience in response to these challenges.

Lesbian and gay parents frequently report having to deal not only with violating hegemonic notions of masculinity and femininity, but with health-care professionals trying to fit them 'into a regular mold' designed for different-sex couples (for example, Rozental and Malmquist 2015, p. 136). Belonging and being recognised is associated with orientating through (social) life without friction (Ahmed 2006). Research on same-sex parent families has repeatedly shown that these families are aware of how, when, and where they differ from other families, and diverge from the normative family ideal.

\section{CONCLUDING DISCUSSION}

In 1997, Sarah Oerton claimed that the diversity of arrangements in gay and lesbian households had failed to remodel and sharpen traditional theories of the division of housework. Two decades later, a growing and rich body of literature - much of which is grounded in empirical research - has improved the theoretical field. However, one question remains: Has this research influenced the larger family sociological debate, and the perspectives and theories in which it is grounded? 
First, we conclude that research on same-sex couples has indeed expanded the family sociological field, calling into question some of the theories that have long guided the field. One perspective that has been challenged is specialisation theory (Becker 1985, 1991). According to this perspective, family utility is maximised when the division of paid work and housework and care is unequally divided, so that each partner specialises in the work in which they are most proficient. Although the power and the resources partners can draw on in negotiations varies in most couples, research has shown that compared with different-sex couples, same-sex couples are, on average, more equal in terms of income and relative resources, and are more capable of negotiating an egalitarian division of paid/unpaid work and care (e.g., Aldén et al. 2015; Evertsson and Boye 2018; Jaspers and Verbakel 2013). There is also evidence that although same-sex couples are not 'genderless' (Biblarz and Savci 2010; Lev 2008), they are more 'gender-free' than different-sex couples (Dunne 1998; Evertsson and Boye 2018; Goldberg 2013). The associations between mothers and housework and childcare on the one hand, and between fathers and paid employment on the other, are strong. Thus, same-sex couples enact their relationships within a larger heteronormative context that has historically assigned a gendered valence to various tasks. This has consequences that cannot be overlooked (Goldberg 2013, p. 87).

As we have shown in this chapter, most research on same-sex couples and parents has acknowledged and drawn on research from the larger family sociological field; a theoretical tradition that seeks to explain the division of work and care in heterosexual couples. Studies on same-sex couples have enriched the field. Research on gay and lesbian families contributes to wider interpretations of families by offering additional insights into how norms and expectations are construed and negotiated in the home, the labour market, and society as a whole (Barrett 2015; Carroll 2018a; Rozental and Malmquist 2015). Nonetheless, research on same-sex couples is rarely cited in research on the division of work and care among different-sex couples and families, even though the former raises questions about the dominant theories that are often used and referenced uncritically in mainstream family sociology. It is our hope that, in the future, the two subfields will be better integrated. Traditional family sociology - and particularly research on normative, heterosexual families - should acknowledge the important findings and theoretical challenges that research on same-sex couples and families have produced.

Finally, we consider the question of to what extent new theories and perspectives have been developed. Our conclusion here is not too far from that of Oerton (1997). Even if research on same-sex couples and parents has called into question theoretical assumptions based on different-sex households, it has not resulted in the development of new theoretical frameworks within the broader field of family sociology. This may be in part because the crucial mechanisms that produce the different patterns of work and care observed among same-sex couples and different-sex couples have not yet been identified. To uncover these mechanisms, a combination of research designs and methods will be needed. One of the more promising approaches is to combine longitudinal, qualitative interviews with quantitative, longitudinal studies of couples. Whereas longitudinal, in-depth interviews provide researchers with insight into the rationales and motives that drive people's decisions, choices, and behaviours as they happen (instead of retrospectively); quantitative research shows the bigger picture, is generalisable, and enables researchers to test theories grounded in qualitative findings. 


\section{ACKNOWLEDGEMENTS}

This project has received funding from the European Research Council under the European Union's Horizon 2020 research and innovation programme awarded to Marie Evertsson (grant agreement No. 771770). We also gratefully acknowledge funding from the Swedish Research Council for Health, Working Life and Welfare (Forte grant agreement No. 2014-2347, principal investigator Marie Evertsson). We would like to thank Maaike van der Vleuten for comments on an earlier draft of the manuscript.

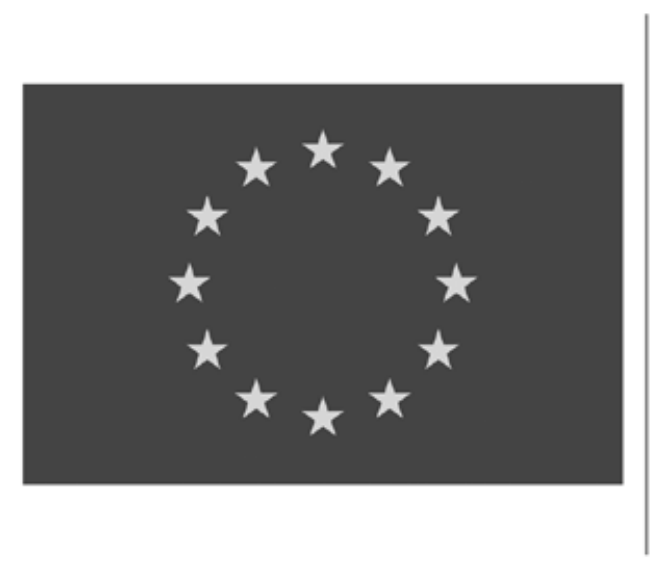

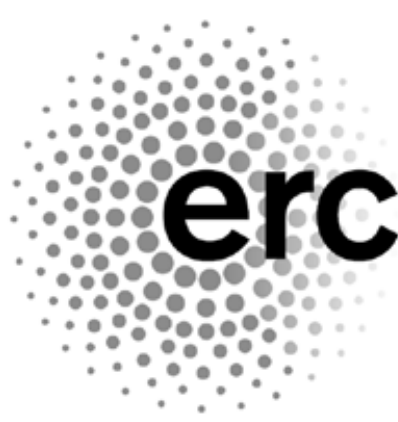

European Research Council

Established by the European Commission

\section{NOTES}

1. LGBTQI is short for lesbian, gay, bisexual, transgender, queer, and intersex.

2. Heteronormativity is the notion that heterosexuality is privileged and constructed, rather than neutral and natural (Jackson 2006; Roseneil et al. 2013). As a concept, heteronormativity was first presented and used by Warner (1993), and has since been influential in various fields, not least in queer theory (Roseneil et al. 2013).

3. Second-parent (or co-parent) adoption is a legal procedure that allows an individual to adopt their partner's biological or adoptive child without terminating the first parent's legal status as a parent (National Center for Lesbian Rights, 2019).

4. An implicit assumption when the relative resource perspective is applied to the division of housework is that people want to minimise the time they spend on housework when it can be replaced by leisure.

5. The terms 'butch' and 'femme' are used to ascribe or acknowledge masculine and feminine identities associated with styles, behaviours, self-perceptions, etc.

\section{REFERENCES}

Ahmed, S. (2006), Queer Phenomenology: Orientations, Objects, Others, Durham, NC: Duke University Press.

Aldén, L., L. Edlund, M. Hammarstedt, and M. Mueller-Smith (2015), 'Effect of registered partnership on labor earnings and fertility for same-sex couples: Evidence from Swedish register data', Demography, 52 (4), 1243-68. doi:10.1007/s13524-015-0403-4. 
Aldén, L., A. Björklund, and M. Hammarstedt (2017), 'Early health and school outcomes for children with lesbian parents: Evidence from Sweden', IZA Discussion Papers, No. 10616, Institute of Labor Economics, Bonn.

Allen, K.R. and A.E. Goldberg (2019), 'Lesbian women disrupting gendered, heteronormative discourses of motherhood, marriage, and divorce', Journal of Lesbian Studies, 24 (1), 12-24. doi:10 $.1080 / 10894160.2019 .1615356$.

Angelov, N., P. Johansson, and E. Lindahl (2016), 'Parenthood and the gender gap in pay', Journal of Labor Economics, 34 (3), 545-79. doi:10.1086/684851.

Antecol, H. and M.D. Steinberger (2013), 'Labor supply differences between married heterosexual women and partnered lesbians: A semi-parametric decomposition approach', Economic Inquiry, 51 (1), 783-805. doi:10.1111/j.1465-7295.2010.00363.x.

Barrett, C. (2015), 'Queering the home: The domestic labor of lesbian and gay couples in contemporary England', Home Cultures, 12 (2), 193-211. doi:10.1080/17406315.2015.1046298.

Bauer, G. (2016), 'Gender roles, comparative advantages and the life course: The division of domestic labor in same-sex and different-sex couples', European Journal of Population, 32 (1), 99-128. doi:10 .1007/s10680-015-9363-z.

Becker G.S. (1985), 'Human capital, effort, and the sexual division of labor', Journal of Labor Economics, 3 (1), 33-58. doi:10.1086/298075.

Becker, G.S. (1991), A Treatise on the Family (enlarged edition), Cambridge, MA: Harvard University Press.

Biblarz, T.J. and E. Savci (2010), 'Lesbian, gay, bisexual, and transgender families', Journal of Marriage and Family, 72 (3), 480-97. doi:10.1111/j.1741-3737.2010.00714.x.

Blood, R.O. and D.M. Wolfe (1960), Husbands and Wives: The Dynamics of Married Living, Glencoe, IL: Free Press.

Boertien, D. and F. Bernardi (2019), 'Same-sex parents and children's school progress: An association that disappeared over time', Demography, 56 (2), 477-501. doi:10.1007/s13524-018-0759-3.

Bos, H.M.W. (2010), 'Planned gay fathers' families in kinship arrangements', Australian and New Zealand Journal of Family Therapy, 31 (4), 356-71. doi:10.1375/anft.31.4.356.

Bos, H.M.W., F. van Balen, and D.C. van den Boom (2003), 'Planned lesbian families: Their desire and motivation to have children', Human Reproduction, 18 (10), 2216-24. doi:10.1093/humrep/deg427.

Brown, S., S. Smalling, V. Groza, and S. Ryan (2009), 'The experiences of gay men and lesbians in becoming and being adoptive parents', Adoption Quarterly, 12 (3-4), 229-46. doi:10.1080/ 10926750903313294.

Butler, J. (1990), Gender Trouble: Feminism and the Subversion of Identity, New York: Routledge.

Carrington, C. (1999), No Place Like Home: Relationships and Family Life among Lesbians and Gay Men, Chicago, IL: University of Chicago Press.

Carroll, M. (2018a), 'Managing without moms: Gay fathers' incidental activism and the politics of parental gender', Journal of Family Issues, 39 (3), 3410-35. doi:10.1177/0192513X18783229.

Carroll, M. (2018b), 'Gay fathers on the margins: Race, class, marital status, and pathway to parenthood', Family Relations, 67 (1), 104-17. doi:10.1111/fare.12300.

Chabot, J. and B. Ames (2004), 'It wasn't "let's get pregnant and go do it": Decision-making in lesbian couples planning motherhood via donor insemination', Family Relations, 53 (4), 348-56. doi:10 $.1111 / \mathrm{j} .0197-6664.2004 .00041 . x$.

Collins, P.H. (1990), Black Feminist Thought: Knowledge, Consciousness and the Politics of Empowerment, New York: Routledge.

Compton, D.R. and A.K. Baumle (2015), Legalizing LGBT Families: How the Law Shapes Parenthood, New York: New York University Press.

Cooke, L.P. (2014), 'Gendered parenthood penalties and premiums across the earnings distribution in Australia, the United Kingdom, and the United States', European Sociological Review, 30 (3), 360-72. doi:10.1093/esr/jcu044.

Cortina, C. and P. Festy (2014), 'Identification of same-sex couples and families in censuses, registers and surveys', FamiliesAndSocieties, Working Paper Series 8.

Crenshaw, K. (1989), 'Demarginalizing the intersection of race and sex: A black feminist critique of antidiscrimination doctrine, feminist theory, and antiracist politics', University of Chicago Legal Forum, 1, 139-67. 
Doucet, A. and R. Lee (2014), 'Fathering, feminism(s), gender, and sexualities: Connections, tensions, and new pathways', Journal of Family Theory and Review, 6 (4), 355-73. doi:10.1111/jftr.12051.

Dunne, G.A. (1998), 'Pioneers behind our own front doors: Towards greater balance in the organisation of work in partnerships', Work, Employment and Society, 12 (2), 273-95. doi:10.1177/ 0950017098122004.

Eckhoff Andresen, M. and E. Nix (2019), 'What causes the child penalty? Evidence from same sex couples and policy reforms', Discussion Papers 902, Statistics Norway, Research Department.

England, P. and M.J. Budig (1998), 'Gary Becker on the family: His genius, impact, and blind spots', in D. Clawson (ed.), Required Reading: Sociology's Most Influential Books, Amherst, MA: University of Massachusetts Press, pp. 99-111.

England, P. and G. Farkas (1986), Households, Employment, and Gender: A Social, Economic, and Demographic View, Hawthorne, NY: Aldine Publishing Co.

Evertsson, M. and K. Boye (2018), 'The transition to parenthood and the division of parental leave in different-sex and female same-sex couples in Sweden', European Sociological Review, 34 (5), 471-85. doi:10.1093/esr/jcy027.

Evertsson, M., E. Jaspers, and Y. Moberg (2020), 'Parentalization of same-sex couples: Family formation and leave rights in five northern European countries', in R. Nieuwenhuis and W. van Lancker (eds), The Palgrave Handbook of Family Policy, Basingstoke: Palgrave Macmillan.

Fischer, M.M., M. Kalmijn, and S. Steinmetz (2016), 'Unions in Context (UNICON): Lesbian, gay, and heterosexual couples, and families in the Netherlands', Dataset, Amsterdam: University of Amsterdam. http://unionsincontext.nl/for-reseachers/.

Frantzen, T. (2011), 'National Report: Norway', American University Journal of Gender Social Policy and Law, 19 (1), 273-6.

Gates, G. (2010), 'Same-sex couples in US Census Bureau data: Who gets counted and why', University of California at Los Angeles California Centre for Population Research, Working Papers 2010-14, at the Williams Institute of the UCLA School of Law.

Goldberg, A.E. (2010), 'Conclusions and future directions', in A.E. Goldberg (ed.), Lesbian and Gay Parents and Their Children: Research on the Family Life Cycle, Washington, DC: American Psychological Association, pp. 177-88.

Goldberg, A.E. (2013), "Doing" and "undoing" gender: The meaning and division of housework in same-sex couples', Journal of Family Theory and Review, 5 (2), 85-104. doi:10.1111/jftr.12009.

Goldberg A.E. and M. Perry-Jenkins (2007), 'The division of labor and perceptions of parental roles: Lesbian couples across the transition to parenthood', Journal of Social and Personal Relationships, 24 (2), 297-318. doi:10.1177/0265407507075415.

Grunow, D., F. Schulz, and H.P. Blossfeld (2012), 'What determines change in the division of housework over the course of marriage?', International Sociology, 27 (3), 289-307. doi:10.1177/ 0268580911423056.

Hequembourg, A.L. and M.P. Farrell (1999), 'Lesbian motherhood: Negotiating marginal-mainstream identities', Gender and Society, 13 (4), 540-57. doi:10.1177/089124399013004007.

Hines S. (2015), 'Feminist theories', in V. Robinson and D. Richardson (eds), Introducing Gender and Women's Studies, London: Red Globe Press, pp. 23-37.

Hull, K.E. and T.A. Ortyl (2019), 'Conventional and cutting-edge: Definitions of family in LGBT Communities', Sexuality Research and Social Policy, 16 (1), 31-43. doi:10.1007/s13178-018-0324-2.

ILGA-Europe (2019), Annual Review of the Human Rights Situation of Lesbian, Gay, Bisexual, Trans, and Intersex People 2019, accessed 12 August 2019 at www.ilga-europe.org/sites/default/files/annual review_2019.pdf.

Jackson, S. (2006), 'Gender, sexuality and heterosexuality: The complexity (and limits) of heteronormativity', Feminist Theology, 7 (1), pp. 105-21. doi:10.1177/1464700106061462.

Jaspers, E. and E. Verbakel (2013), 'The division of paid labour in same-sex couples in the Netherlands', Sex Roles, 68 (5-6), 335-48. doi:10.1007/s11199-012-0235-2.

Jepsen, C. and L.K. Jepsen (2015), 'Labour-market specialization within same-sex and difference-sex couples', Industrial Relations: A Journal of Economy and Society, 54 (1), 109-30. doi:10.1111/irel .12078 .

Kolk, M. and G. Andersson (2018), 'Two decades of same-sex marriage in Sweden: A demographic account of developments in marriage, childbearing and divorce', Stockholm Research Reports 
in Demography 2018/19, Stockholm University, Linnaeus Centre on Social Policy and Family Dynamics in Europe.

Kurdek, L.A. (1993), 'The allocation of household labour in gay, lesbian, and heterosexual married couples', Journal of Social Issues, 49 (3), 127-39. doi:10.1111/j.1540-4560.1993.tb01172.x.

Kurdek, L.A. (2007), 'The allocation of household labour by partners in gay and lesbian couples', Journal of Family Issues, 28 (1), 132-48. doi:10.1177/0192513X06292019.

Lev, A.I. (2008), 'More than surface tensions: Femmes in families', Journal of Lesbian Studies, 12 (2-3), 127-44. doi:10.1080/10894160802161299.

Lundberg, S. and R.A. Pollak (1996), 'Bargaining and distribution in marriage', Journal of Economic Perspectives, 10 (4), 139-58. doi:10.1257/jep.10.4.139.

Malmquist, A. (2015), Pride and Prejudice: Lesbian Families in Contemporary Sweden, Dissertation, Department of Behavioural Sciences and Learning of Linköping University Faculty of Arts and Sciences.

Malmquist, A. and K.Z. Nelson (2014), 'Efforts to maintain a "just great" story: Lesbian parents' talk about encounters with professionals in fertility clinics and maternal and child healthcare services', Feminism and Psychology, 24 (1), 56-73. doi:10.1177/0959353513487532.

Mazrekaj, D., K. De Witte, and S. Cabus (2019), 'School outcomes of children raised by same-sex couples: Evidence from administrative panel data', Paper presented at the Conference of the American Economic Association, 5 January.

Moberg, Y. (2016), 'Does the gender composition in couples matter for the division of labor after child birth?', Institute for Evaluation of Labour Market and Education Policy (IFAU), Working Paper 2016/8.

Moberg, Y. (2017), Gender, Incentives and the Division of Labour, Dissertation Series 2017/3, Department of Economics of Uppsala University.

Moore, M.R. and M. Stambolis-Ruhstorfer (2013), 'LGBT sexuality and families at the start of the twenty-first century', Annual Review of Sociology, 39, 491-507. doi:10.1146/annurev-soc $-071312-145643$.

Moreira, L. (2018), 'Queer motherhood: Challenging heteronormative rules beyond the assimilationist/ radical binary', Journal of International Women's Studies, 19 (2), 14-28.

National Center for Lesbian Rights (2019), Legal Recognition of LGBT Families, accessed 5 December 2019 at www.nclrights.org/wp-content/uploads/2013/07/Legal_Recognition_of_LGBT_Families.pdf.

National Healthcare Institute (2019a), Vergoeding KID (kunstmatige inseminatie met donorzaad) vanuit de Zorgverzekeringswet, accessed 4 December 2019 at www.zorginstituutnederland.nl/publicaties/ publicatie/2019/02/25/zorgverzekeringswet-en-kid-kunstmatige-inseminatie-met-donorzaad.

National Healthcare Institute (2019b), Tijdelijke Overgangsregeling KID, accessed 4 December 2019 at www.zorginstituutnederland.nl/publicaties/publicatie/2019/03/13/tijdelijke-overgangsregeling\%E2 $\% 80 \% 99$-kid.

Oerton, S. (1997), “"Queer housewives?” Some problems in theorising the division of domestic labour in lesbian and gay households', Women's Studies International Forum, 20 (3), 421-30. doi:10.1016/ S0277-5395(97)00025-3.

Park, N.K., E. Kazyak, and K. Slauson-Blevins (2016), 'How law shapes experiences of parenthood for same-sex couples', Journal of GLBT Family Studies, 12 (2), 115-37. doi:10.1080/1550428X.2015 .1011818 .

Patterson, C.J., E.L. Sutfin and M. Fulcher (2004), 'Division of labor among lesbian and heterosexual parenting couples: Correlates of specialized versus shared patterns', Journal of Adult Development, 11 (3), 179-89. doi:1068-0667/04/0700-0179/0.

Perlesz, A., J. Power, R. Brown, R. McNair, M. Schofield, M. Pitts, and A. Bickerdike (2010), 'Organising work and home in same-sex parented families: Findings from the work love play study', Australian and New Zealand Journal of Family Therapy, 31 (4), 374-91. doi:10.1375/anft.31.4.374.

Risman, B.J. and G. Davis (2013), 'From sex roles to gender structure', Current Sociology Review, 61 (5-6), 733-55. doi:10.1177/0011392113479315.

Rosenbaum, P. (2019), The Family Earnings Gap Revisited: A Household or a Labour Market Problem?, Department of Economics at the Copenhagen Business School of the University of Copenhagen. doi: $10.2139 /$ ssrn.3314102. 
Roseneil, S., I. Crowhurst, T. Hellesund, A.C. Santos, and M. Stoilova (2013), 'Changing landscapes of heteronormativity: The regulation and normalization of same-sex sexualities in Europa', Social Politics, 20 (2), 165-99. doi:10.1093/sp/jxt006.

Rozental, A. and A. Malmquist (2015), 'Vulnerability and acceptance: Lesbian women's family-making through assisted reproduction in Swedish public health care', Journal of GLBT Family Studies, 11 (2), 127-50. doi:10.1080/1550428X.2014.891088.

Rudlende, L. and I. Lima (2018), 'Medmødre tilpasser seg også fedrekvoten', Arbeid of Velferd, 3, $25-38$

Silverstein L.B., C.F. Auerbach, and R.F. Levant (2002), 'Contemporary fathers reconstructing masculinity: Clinical implications of gender role strain', Professional Psychology: Research and Practice, 33 (4), 361-9. doi:10.1037//0735-7028.33.4.361.

Stacey, J. (2006), 'Gay parenthood and the decline of paternity as we knew it', Sexualities, 9 (1), 27-55. doi:10.1177/1363460706060687.

Tornello, S.L., S.M. Kruczkowski, and C.J. Patterson (2015), 'Division of labor and relationship quality among male same-sex couples who became fathers via surrogacy', Journal of GLBT Family Studies, 11 (4), 375-94. doi:10.1080/1550428X.2015.1018471.

Van der Vleuten, M., E. Jaspers, and T. van der Lippe (2021), 'Same-sex couples' division of labor from a cross-national perspective', Journal of GLBT Family Studies, 17 (2), 150-167. doi:10.1080/ $1550428 X .2020 .1862012$.

Vinjamuri, M. (2015), 'Reminders of heteronormativity: Gay adoptive fathers navigating uninvited social interactions', Family Relations, 64 (2), 263-77. doi:10.1111/fare.12118.

Waaldijk, K. (ed.) (2017), 'More and more together: Legal family formats for same-sex and different-sex couples in European countries: Comparative analysis of data in the LawsAndFamiliesDatabase', FamiliesAndSocieties Working Paper Series 2017/75, Stockholm University.

Waaldijk, C. (2018), 'Extending rights, responsibilities and status to same-sex families: Trends across Europe', Ministry of Foreign Affairs of Denmark, for Council of Europe.

Warner, M. (ed.) (1993), Fear of a Queer Planet: Queer Politics and Social Theory, Minneapolis, MN: University of Minnesota Press.

West, C. and S. Fenstermaker (eds) (2002), Doing Gender, Doing Difference: Inequality, Power, and Institutional Change, New York: Routledge.

West, C. and D.H. Zimmerman (1987), 'Doing gender', Gender and Society, 1 (2), 125-51. doi:10.1177/ 0891243287001002002 .

Weston, K. (1991), Families We Choose: Lesbians, Gays, Kinship, New York: Columbia University Press. 